\title{
Nanotheranostics
}

2018; 2(1): 59-69. doi: 10.7150/ntno.22754

Research Paper

\section{Oxygen Self-Sufficient Amphiphilic Polypeptide Nanoparticles Encapsulating BODIPY for Potential Near Infrared Imaging-guided Photodynamic Therapy at Low Energy}

\author{
Le Liu, Zheng Ruan, Pan Yuan, Tuanwei Li, and Lifeng Yan ${ }^{凶}$ \\ CAS Key Laboratory of Soft Matter Chemistry, Department of Chemical Physics, iCHEM, University of Science and Technology of China. Hefei, 230036, P.R. \\ China. \\ $\bowtie$ Corresponding author: Lifeng Yan, Fax: +86-551-63603748; Tel: +86-551-63606853; E-mail: 1fyan@ustc.edu.cn \\ (c) Ivyspring International Publisher. This is an open access article distributed under the terms of the Creative Commons Attribution (CC BY-NC) license \\ (https://creativecommons.org/licenses/by-nc/4.0/). See http://ivyspring.com/terms for full terms and conditions.
}

Received: 2017.09.08; Accepted: 2017.11.10; Published: 2018.01.01

\begin{abstract}
Near infrared (NIR) imaging-guided photodynamic therapy (PDT) is remarkable for its high-efficiency in "see and treat" field. However, hypoxia of cancer cell limits PDT dues to the low singlet oxygen yield. Here $\mathrm{MnO}_{2}$ conjugated multifunctional polypeptide nanoparticles encapsulating photosensitizer BODIPY has been prepared via a one-step reaction, which can generate oxygen in cancer cytoplasm where rich of $\mathrm{H}_{2} \mathrm{O}_{2}$, following singlet oxygen by photosensitizer under NIR light irradiation. In vitro studies on HepG2 and $4 \mathrm{~T} 1$ cancer cells revealed that the as-prepared nanoparticles obviously increase the cell suppression rate under hypoxia conditions, even exposed to an extremely low light energy density $\left(25 \mathrm{~mW} / \mathrm{cm}^{2}\right)$. Meanwhile, excellent NIR fluorescence property of BODIPY enabled the nanoparticles to light up the cancer cells for real-time imaging. These results suggest the promises of biocompatible and biodegradable nanoparticles has potential application on efficient NIR imaging-guided photodynamic therapy.
\end{abstract}

Key words: polypeptide nanoparticles, photodynamic therapy (PDT), near-infrared fluorescence (NIRF), imaging-guided, hypoxia

\section{Introduction}

Photodynamic therapy (PDT), which kills cancer cells by reactive oxygen species (ROS) when photosensitizers (PSs) were exposed to light in the presence of oxygen, has attracted increasing attention in recent years.[1-3] To achieve imaging-guided PDT, excellent PSs needs to have both high near-infrared (NIR) emission and singlet oxygen $\left({ }^{1} \mathrm{O}_{2}\right)$ generation efficiency, $[4,5]$ among which heavy atoms modified 4, 4-difluoro-4-bora-3a, a-diaza-s-indacene (BODIPY) PSs have been widely studied.[6, 7]

However, most of the existing BODIPY PSs are usually too hydrophobic to be delivered to the tumor tissues. To solve this problem, a variety of nanomaterials (liposomes, polymers, quantum dots, metallic nanostructures, etc.) have been designed,[8-11] among which amphiphilic polymer nanoparticles have been proved effective in protecting PSs from water invasion.[12-14] Besides, the well-designed compositions, sizes, morphologies make polymer-PS NPs easily accumulate in the tumor tissue through enhanced permeability and retention (EPR) effect, and then present effective PDT under light irradiation.[15]

Oxygen is necessary for PDT for the efficient generation of singlet oxygen. Unfortunately, hypoxia is a common characteristic of the tumor microenvironment (TME) resulting from the rapid growth of cancer cells.[16] Moreover, oxygen consumption to ${ }^{1} \mathrm{O}_{2}$ during PDT can aggravate the insufficient oxygen supply, which will in turn 
hampers PDT from achieving its full photodynamic efficacy.[17, 18] Various strategies have been explored to overcome this problem, including dividing irradiation into dark-light circles to affect PDT-induced oxygen depletion, transport oxygen to tumor tissues with artificial blood substitutes, and in situ oxygen generation with catalysts inside tumors.[19-21] Since manganese dioxide $\left(\mathrm{MnO}_{2}\right)$ shows high reactivity toward $\mathrm{H}_{2} \mathrm{O}_{2}$ to produce $\mathrm{O}_{2}$, it is predicted to supply $\mathrm{O}_{2}$ to tumor microenvironment or inside cancer cell since the concentration of $\mathrm{H}_{2} \mathrm{O}_{2}$ is higher therein.[22] More importantly, the reaction between $\mathrm{MnO}_{2}$ and $\mathrm{H}_{2} \mathrm{O}_{2}$ under acidic $\mathrm{pH}$, which is not purely catalytic, can consume $\mathrm{MnO}_{2}$ to break down to harmless $\mathrm{Mn}^{2+}$ ions. These characteristics could be particularly favorable for biological applications with less accumulating toxicity in the body.

Envisioning the effectiveness of the $\mathrm{MnO}_{2}$-catalyzed $\mathrm{H}_{2} \mathrm{O}_{2}$ decomposition to produce $\mathrm{O}_{2}$ to overcome the hypoxia situation in PDT, we have developed biocompatible $\mathrm{MnO}_{2}$ and BODIPY loaded NPs (PMB NPs) and verified their multifunctionality in eliminating hypoxia and then high-efficiently killing cancer cells with light irradiation. Polypeptides were chose in our study for their biocompatibility and biodegradability,[23] and easy preparation via ring-opening polymerization of $\mathrm{N}$-carboxyanhydrides monomer (NCA). So firstly, an amino-functionalized copolymer (POEGMA-PLys) was prepared, in which POEGMA worked for its stabilization in aqueous environment. Then after the loading of $\mathrm{MnO}_{2}$ and BODIPY, the as-prepared polymer- $\mathrm{MnO}_{2^{-}}$ BODIPY (PMB NPs) were demonstrated to possess the following abilities: (1) remitting hypoxia via reaction of $\mathrm{MnO}_{2}$ towards $\mathrm{H}_{2} \mathrm{O}_{2}$ to generate amounts of $\mathrm{O}_{2}$ in situ, (2) increasing $\mathrm{pH}$ by consuming protons during the above reaction, (3) tracing cancer cells relying on the high fluorescence emission of BODIPY, and (4) suppressing cancer cells growth in the presence of $\mathrm{H}_{2} \mathrm{O}_{2}$ and light under hypoxia condition. Taken together, oxygen self-sufficient nanoparticles carrying BODIPY for simultaneous low energy triggered imaging and treating has been prepared.

\section{Experimental Section}

\section{Materials}

Organic solvents were purchased from Sinoreagent Corporation. N, N-dimethyl formamide (DMF), tetrahydrofunan (THF), dichloromethane (DCM) and n-hexane were dried over $\mathrm{CaH}_{2}$ before use. All reagents in AR purity were purchased from Aladdin Corporation (China) and used without further purification. Oligo (ethylene glycol) methacrylate (OEGMA) was purified using silica gel before immediate polymerization. Dulbecco modified eagle medium (DMEM), fetal bovine serum (FBS), fluorescein diacetate (FDA), propidium iodide (PI), 4',6-diamidino-2-phenylindole (DAPI) and methyl thiazolyl tetrazolium (MTT) were purchased from Sangon Corporation (China). A Milli-Q (18.2 M 2 ) Synthesis System (Millipore, Bedford, MA, USA) was used to prepare ultrapure water. Dialysis bags (cut off $\mathrm{M}_{\mathrm{w}}=7000$ or 1000) were obtained from Bomei Biotechnology Corporation (China).

\section{Characterization}

${ }^{1} \mathrm{H}-\mathrm{NMR}$ spectra, using either DMSO-d6 or $\mathrm{CDCl}_{3}$ containing $0.03 \% \quad(\mathrm{v} / \mathrm{v})$ TMS as solvent, were measured on a Bruker AC 300 NMR spectrometer. UV-Vis spectra were measured on a Shimadzu UV-2401 PC Ultraviolet while fluorescence spectra were recorded on Shimadzu RF-5301PC. FT-IR spectra, applying a $\mathrm{KBr}$ method, were recorded on a Bruker EQUINOX 55 spectrometer. The molecular weights of the prepared samples $(5 \mathrm{mg} / \mathrm{mL})$ were determined with gel permeation chromatography (GPC, KD-804 column and RID-10A refractive index detector), using DMF as the mobile phase at $60{ }^{\circ} \mathrm{C}$. Raman spectra were recorded on a Bruker spectromet er with a 532nm laser. Dynamic light scattering (DLS) were measured via a Malvern Zetasizer Nano ZS90. JEOL-2010 microscope was used to obtain transmission electron microscopy (TEM) images. The fluorescence microscope imaging experiments were conducted on an Olympus U-HGLGPS fluorescence microscope. A Bio-rad iMark microplate reader was applied to record the MTT absorbance. The dissolved oxygen is estimated by a dissolved oxygen meter AZ 8403 at room temperature.

\section{Methods}

Synthesis of POEGMA 30 (1)

RAFT-APA (230mg, $0.474 \mathrm{mmol})$, OEGMA (11.8g, $23.7 \mathrm{mmol}, 50$ equiv) and AIBN (13.5mg, 0.118 mmol, $1 / 4$ equiv) were dissolved in DMF $(5 \mathrm{~mL})$ into a flame dried and argon purged Schlenk tube and stirred at $80{ }^{\circ} \mathrm{C}$ for $12 \mathrm{~h}$. After cooling to room temperature, the solution was purified by dialysis using ultrapure water and freeze dried to obtain a yellow viscous liquid $(6.42 \mathrm{~g}, 90.3 \%)$. (Figure S5)

\section{Synthesis of PLys 10 (2)}

Firstly, Ne-Carbobenzoxy-L-lysine $(2.74 \mathrm{~g}, 9.82$ $\mathrm{mmol})$ and triphosgene $(3.19 \mathrm{~g}, 10.8 \mathrm{mmol}, 1.1$ equiv) was mixed in dry DMF $(40 \mathrm{~mL})$ under a nitrogen atmosphere and stirred at $45^{\circ} \mathrm{C}$ for $2 \mathrm{~h}$. After cooling in an ice-water bath, crystallized with dried hexane 
and THF, white solid Lys-NCA was obtained and was dried over a vacuum line for $4 \mathrm{~h}$.

Then propargylamine $(35.8 \mathrm{mg}, 0.650 \mathrm{mmol})$ was solubilized in dry DMF (10 mL) into a flame dried and argon purged Schlenk tube. And Lys-NCA $(1.99 \mathrm{~g}$, $6.50 \mathrm{mmol}, 10$ equiv) in dry DMF $(8 \mathrm{~mL})$ was added at $0{ }^{\circ} \mathrm{C}$ and kept stirring for 3 days. After stirring at room temperature overnight, the solution was purified by dialysis with ultrapure water and freeze dried to get a white solid (1.75g, 92.0\%). (Figure S5)

\section{Synthesis of POEGMA 30 -PLys 10 (3)}

To a flame dried and argon purged Schlenk tube, $2(915 \mathrm{mg}, 61.0 \mu \mathrm{mol})$ and $3(164 \mathrm{mg}, 61.0 \mu \mathrm{mol})$ were dissolved in DMF $(10 \mathrm{~mL})$, and then $\mathrm{CuBr}(8.9 \mathrm{mg}, 61.0$ $\mu \mathrm{mol})$ and PMDETA $(10.5 \mathrm{mg}, 61.0 \mu \mathrm{mol})$ was added to give a click reaction at $30^{\circ} \mathrm{C}$ for 3 days. The solution was purified by dialysis with EDTA added ultrapure water and freeze dried to obtain a yellow solid (671mg, 83.5\%).

\section{Amino Deprotection of Polymer 3 (4)}

Polymer 3 (350mg, $1.97 \mu \mathrm{mol})$ was dissolved in trifluoroacetic acid $(5 \mathrm{~mL})$ and $\mathrm{HBr}$-acetic acid (33 $w t \%, 500 \mu \mathrm{L}$ ) was then added in an ice-water bath. After stirring for $5 \mathrm{~h}$ at room temperature, the solution was precipitated and washed with excess diethyl ether to get a sticky yellow solid (302mg, 92.2\%).

\section{Preparation of Polymer- $\mathrm{MnO}_{2}$ Nanoparticles (PM NPs)}

PM NPs were prepared by directly mixing the aqueous solutions of amino-contained polymer 4 and $\mathrm{KMnO}_{4}$. Briefly, $100 \mu \mathrm{L}$ of $\mathrm{KMnO}_{4}$ solution (14.3 $\mathrm{mg} / \mathrm{mL}$ ) was added into $5 \mathrm{~mL}$ of polymer $(30 \mathrm{mg}$ ) solution, and the mixture was stirred for $20 \mathrm{~min}$ at room temperature. The conversion of permanganate to $\mathrm{MnO}_{2}$ was confirmed by recording UV-vis absorption spectrum. Finally a filter membrane $(450 \mathrm{~nm})$ was applied to remove the unstable particles.

\section{Preparation of Polymer- $\mathrm{MnO}_{2}-\mathrm{BODIPY}$ \\ Nanoparticles (PMB NPs)}

PMB NPs were prepared by emulsion-volatilization method. In brief, $5 \mathrm{~mL}$ of the as-prepared PM NPs solution and $0.3 \mathrm{~mL}$ BODIPY (5mg) in $\mathrm{CH}_{2} \mathrm{Cl}_{2}$ were mixed to get emulsion with ultrasonic treatment. Then $\mathrm{CH}_{2} \mathrm{Cl}_{2}$ was removed by volatilization and a filter membrance $(450 \mathrm{~nm})$ was applied to remove the unstable particles.

\section{Detection of Singlet Oxygen.}

Singlet oxygen generation of PMB NPs was detected using a 635 lamp at $25 \mathrm{~mW} / \mathrm{cm}^{2}$. PMB NPs and DPBF were dissolved in $2 \%$ DMSO contained deionized water and irradiated with light. The absorbance of the solution was measured at every predetermined time points. The absorbance reduction of DPBF was considered to quantify the ${ }^{1} \mathrm{O}_{2}$ generation efficiency.

\section{Cell Lines and Cytocompatibility}

Human HepG2 and murine 4T1 cells obtained from American Type Culture Collection were incubated in DMEM or 1640 medium respectively (containing $10 \%$ FBS) at $37{ }^{\circ} \mathrm{C}$ under $5 \% \quad \mathrm{CO}_{2}$ atmosphere.

The cytocompatibility of PMB NPs over HepG2 and 4T1 cells was conducted using a standard MTT assay. In brief, HepG2 or 4T1 cells (3000 cells per well) were seeded onto 96-well plates and allowed to incubate for $24 \mathrm{~h}$. Fresh medium with PMB NPs (0-0.3 $\mathrm{mg} / \mathrm{mL}$ ) were added and incubated for $8 \mathrm{~h}$. After medium was changed incubated overnight, MTT was added and incubated for $4 \mathrm{~h}$. The absorbance of cell lysate in DMSO $(150 \mu \mathrm{L})$ was measured at $570 \mathrm{~nm}$.

\section{Cellular Uptake of NPs.}

HepG2 and 4T1 tumor cells $\left(10^{5}\right.$ cells per well) were plated onto 6-well plates and incubated for $24 \mathrm{~h}$. Then fresh medium with PMB NPs $(0.3 \mathrm{mg} / \mathrm{mL})$ was added and incubated for a scheduled time. After fixed with $4 \%$ formaldehyde, cell nuclei were stained blue with DAPI (100 ng/mL) and observed through a fluorescence microscope.

\section{In Vitro Photodynamic Therapy and Cell Apoptosis}

For photodynamic therapy experiments, HepG2 or 4T1 cells (3000 cells per well) were seeded onto 96-well plates and incubated for $24 \mathrm{~h}$. Then fresh medium with PMB or PB NPs $(0-0.3 \mathrm{mg} / \mathrm{mL})$ were added and incubated for $8 \mathrm{~h}$ under normal or $\mathrm{N}_{2}$ atmosphere. After irradiated for $10 \mathrm{~min}(635 \mathrm{~nm}, 25$ $\mathrm{mW} / \mathrm{cm}^{2}$ ) or not, medium was changed and cells were incubated overnight. A standard MTT protocol was used to measure cell viability. Experimental groups with $\mathrm{H}_{2} \mathrm{O}_{2}(100 \mu \mathrm{M})$ added $4 \mathrm{~h}$ before irradiation was also conducted.

Observable laser-induced PDT effect was presented by staining experiments of live or dead cells. HepG2 and $4 \mathrm{~T} 1$ tumor cells $\left(10^{5}\right.$ cells per well) were plated onto 6-well plates and incubated for $24 \mathrm{~h}$. Then fresh medium with PMB or PB NPs $(0.3$ $\mathrm{mg} / \mathrm{mL}$ ) was added and incubated for $8 \mathrm{~h}$ under normal or hypoxia $\left(\mathrm{N}_{2}\right)$ atmosphere. After $10 \mathrm{~min}$ irradiation $\left(635 \mathrm{~nm}, 25 \mathrm{~mW} / \mathrm{cm}^{2}\right)$ or not, medium was changed and the cells were allowed to incubate overnight. Then live or dead cells were stained with FDA $(10 \mu \mathrm{g} / \mathrm{mL})$ or PI $(100 \mu \mathrm{g} / \mathrm{mL})$ respectively for $15 \mathrm{~min}$ at $37^{\circ} \mathrm{C}$, and observed through a fluorescence microscope. Experimental groups with $\mathrm{H}_{2} \mathrm{O}_{2}(100 \mu \mathrm{M})$ added $4 \mathrm{~h}$ before irradiation was also conducted. 
Cell apoptosis experiments were conducted applying cell nuclei staining assay using DAPI against HepG2 tumor cells $\left(10^{5}\right.$ cells per well). After plated and incubated for $24 \mathrm{~h}$, cells were cultured with fresh medium with PMB or PB NPs (BODIPY $10 \mu \mathrm{M}$ ) for another $12 \mathrm{~h}$ and then exposed to light $(635 \mathrm{~nm}, 25$ $\mathrm{mW} / \mathrm{cm}^{2}$ ) or not. After fixed with $4 \%$ formaldehyde, cell nuclei were stained blue with DAPI $(100 \mathrm{ng} / \mathrm{mL})$ and observed through a fluorescence microscope for a scheduled time.

\section{Results and Discussion}

\section{Preparation of PMB NPs}

To efficiently load $\mathrm{MnO}_{2}$ and deliver PSs, we designed an amphiphilic block polymer, in which poly-oligo (ethylene glycol) methacrylate (POEGMA) worked as a hydrophilic shell, and peptides as a hydrophobic core. As shown in Scheme 1, an azido modified RAFT agent was firstly prepared according to our previous work,[24] and then used to RAFT-polymerize OEGMA (PDI=1.17, Table 1). Meanwhile, ring-opening polymerization (ROP) of Lys-NCA was conducted applying propargylamine as the initiator to obtain PLys 10 (PDI=1.14). After the click reaction of these two segments, the copolymer was exposed to $\mathrm{HBr}$ to carry out amino deprotection for the latter reduction reaction of manganese permanganate. Completion of click reaction could be

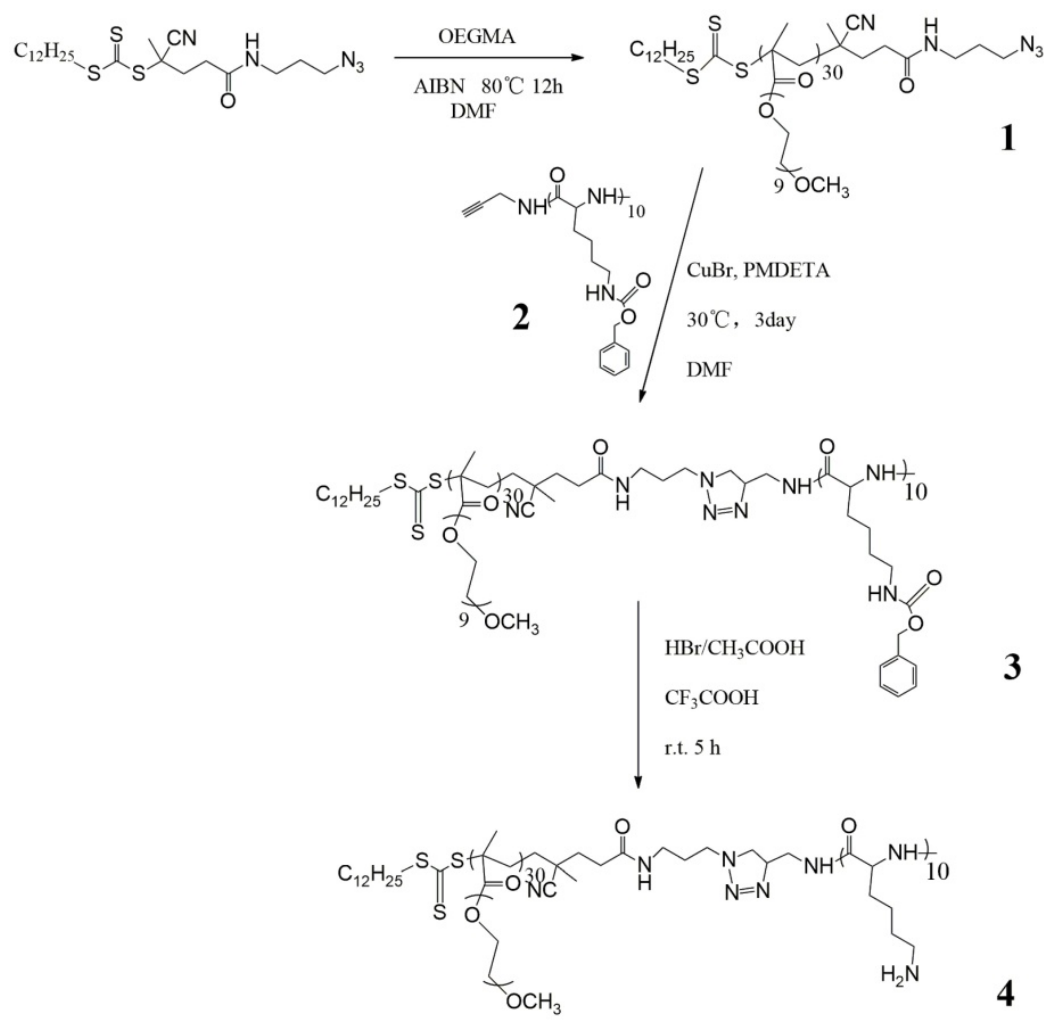

Scheme 1. Synthesis of the amino-contained amphiphilic copolymer. proved by the disappearance of $2063 \mathrm{~cm}^{-1}$ peak of $\mathrm{N}_{3}$ in FT-IR spectra (Figure S1) and the increase in molecular weight of the polymer (Figure S2). The disappearance of benzene peaks in ${ }^{1} \mathrm{H}-\mathrm{NMR}$ spectra proved the preparation of amino-contained copolymer. As shown in Figure 1, after the amino deprotection of copolymer, the peaks of benzyl groups disappeared (4.98ppm and 7.30ppm) while the chemical shift of protons $\mathrm{m}$ slightly moved to a higher field (from 2.94ppm to 2.78ppm).

Table 1. Molecular weights and polydispersity indexes of the obtained copolymers.

\begin{tabular}{llll}
\hline Sample & $\mathrm{M}_{\mathrm{n}} \mathrm{NMR}$ & $\mathrm{M}_{\mathrm{n}}$ GPC & PDI \\
\hline PLys 10 & 2675 & 2760 & 1.14 \\
POEGMA $_{30}$ & 15485 & 16725 & 1.17 \\
POEGMA $_{30}$ PLys $_{10}$ & 19400 & 21240 & 1.12 \\
POEGMA $_{30}$-PLys $\left(\mathrm{NH}_{2}\right)_{10}$ & 17030 & - & - \\
\hline
\end{tabular}

It has been reported that $\mathrm{KMnO}_{4}$ could be reduced to $\mathrm{MnO}_{2}$ by organic amine compounds,[25, 26] so we employed a one-step method using the as-prepared amino-involved polymer to reduce $\mathrm{KMnO}_{4}$ to get polymer- $\mathrm{MnO}_{2}$ (PM NPs) in $20 \mathrm{~min}$, as shown in Figure 2a. The solution color would gradually change from purple to brown, until the UV-vis absorption peak of $\mathrm{KMnO}_{4}$ disappeared. Peaks at 507, 571, $646 \mathrm{~cm}^{-1}$ in the Raman spectrum (Figure $2 b)$ of PMB confirmed the generation of $\gamma-\mathrm{MnO}_{2}$.[27] XRD spectrum of the PMB nanoparticles in Figure 2c shows four broad diffraction peaks at $24.4^{\circ}, 37.7^{\circ}, 52.6^{\circ}$ and $65.9^{\circ}$. Meanwhile XPS spectra of PMB NPs could be roughly detected, and in the Mn $2 \mathrm{p}$ pattern, two main peaks located at $654.1 \mathrm{eV}(\mathrm{Mn} \mathrm{2p} 1 / 2)$ and $642.6 \mathrm{eV}(\mathrm{Mn}$ $2 \mathrm{p} 2 / 3$ ) with a spin-energy separation of $11.6 \mathrm{eV}$.[28] The broad peaks in XRD and weak signals in XPS all revealed the poor crystallization of PMB mainly caused by the coverage of polymers on the surface of $\mathrm{MnO}_{2}$. The polymer used here served as not only a reducing reagent, but also a protective layer to stabilize the as-formed NPs. This procedure was rapid and gave stable PM dispersions with an average size distribution of 50.8nm (Figure 3a, 3c).

It was reported that heavy atoms modified BODIPY dyes displayed outstanding properties, such as high NIR absorbance and fluorescence emission, especially their massive singlet oxygen generation.[29] So an excellent BODIPY dye was synthesized according to our precious work (Scheme S1), and it shows 
a $\lambda_{\max }=721 \mathrm{~nm}$ with $\lambda_{\mathrm{em}}=788 \mathrm{~nm}, \phi_{\Delta}\left({ }^{1} \mathrm{O}_{2}\right)=0.36 \mathrm{in}$ $\mathrm{CHCl}_{3}$ (Figure S3).[30] The BODIPY molecules were encapsulated into PMB NPs by an emulsion method for efficient NIR imaging and PDT. It could be effectively introduced to the core of NPs by the hydrophobic interaction between $\mathrm{MnO}_{2}$ and BODIPY, and the photosensitizer loading content (PLC) was calculated to be about 3.2\% applying the following equation, as measured by UV-vis absorbance spectra.

PLC $($ wt $\%)=\left(\frac{\text { weight of loaded photosensitizer }}{\text { weight of NPs }}\right) \times 100 \%$
When BODIPY dye is added to the reaction mixture, the nanoparticles turned much bigger mainly caused by the severe hydrophobicity of BODIPY, leading to a further aggregation of NPs core. DLS showed PMB NPs had an average sizes distribution of $169.2 \mathrm{~nm}$ (Figure 3b), and the Zeta potential was $+14.5 \mathrm{mV}$ due to the existence of $\mathrm{MnO}_{2}$, which could befit the NPs enter the tumor cells. TEM images were accordant with the DLS results, and further revealed their nano-size and spherical shape (Figure 3d).

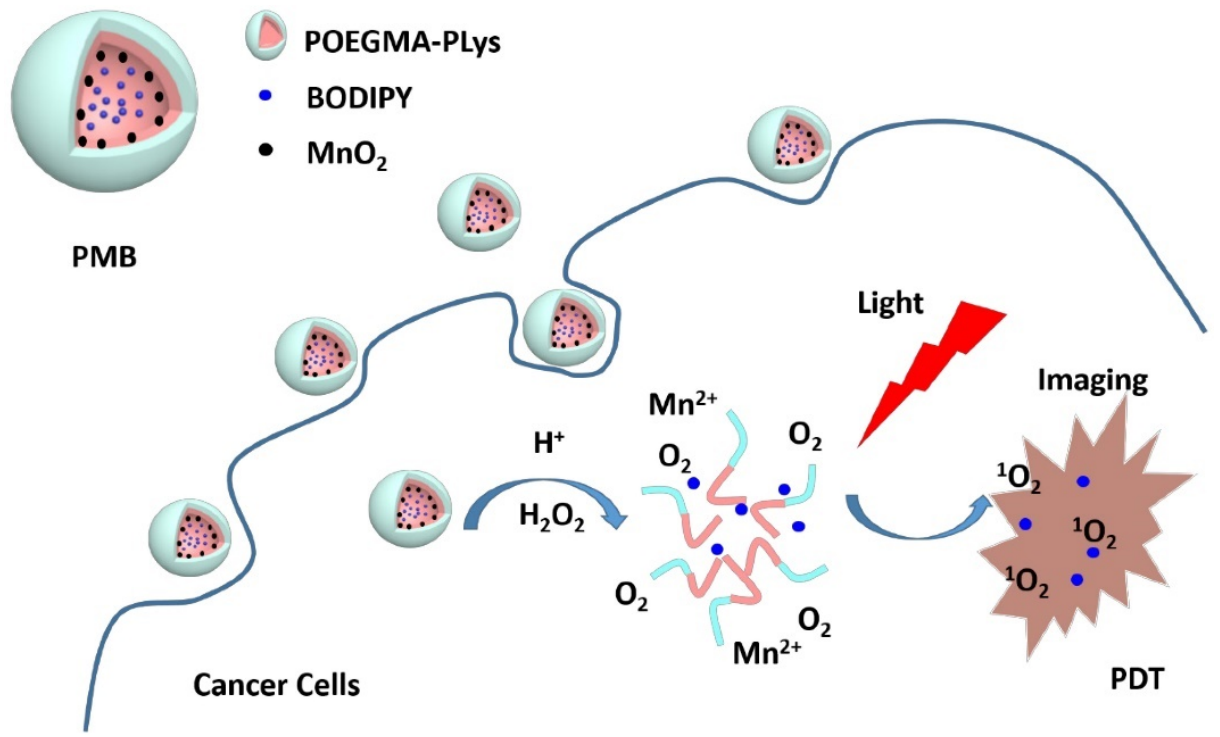

Scheme 2. PMB NPs reacting with endogenous $\mathrm{H}_{2} \mathrm{O}_{2}$, NIR imaging and photodynamic therapy on cancer cells.

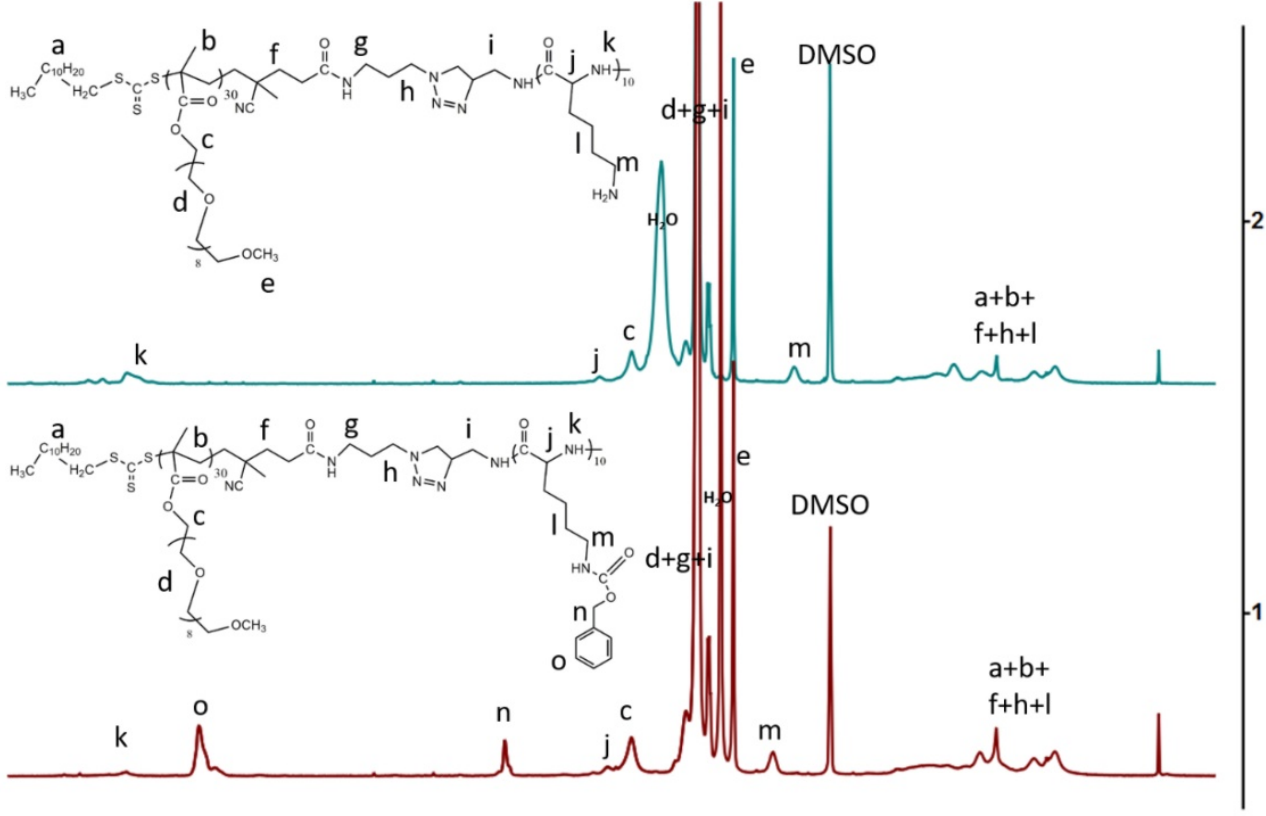

$\begin{array}{llllllllllllllllll}8.5 & 8.0 & 7.5 & 7.0 & 6.5 & 6.0 & 5.5 & 5.0 & 4.5 \underset{\mathrm{ppm}}{4.0} & 3.5 & 3.0 & 2.5 & 2.0 & 1.5 & 1.0 & 0.5 & 0.0\end{array}$

Figure 1. 'H-NMR spectra comparison of (1) POEGMA $30-P L y s 10$ and (2) POEGMA $30-P L y s\left(\mathrm{NH}_{2}\right)_{10}$. 

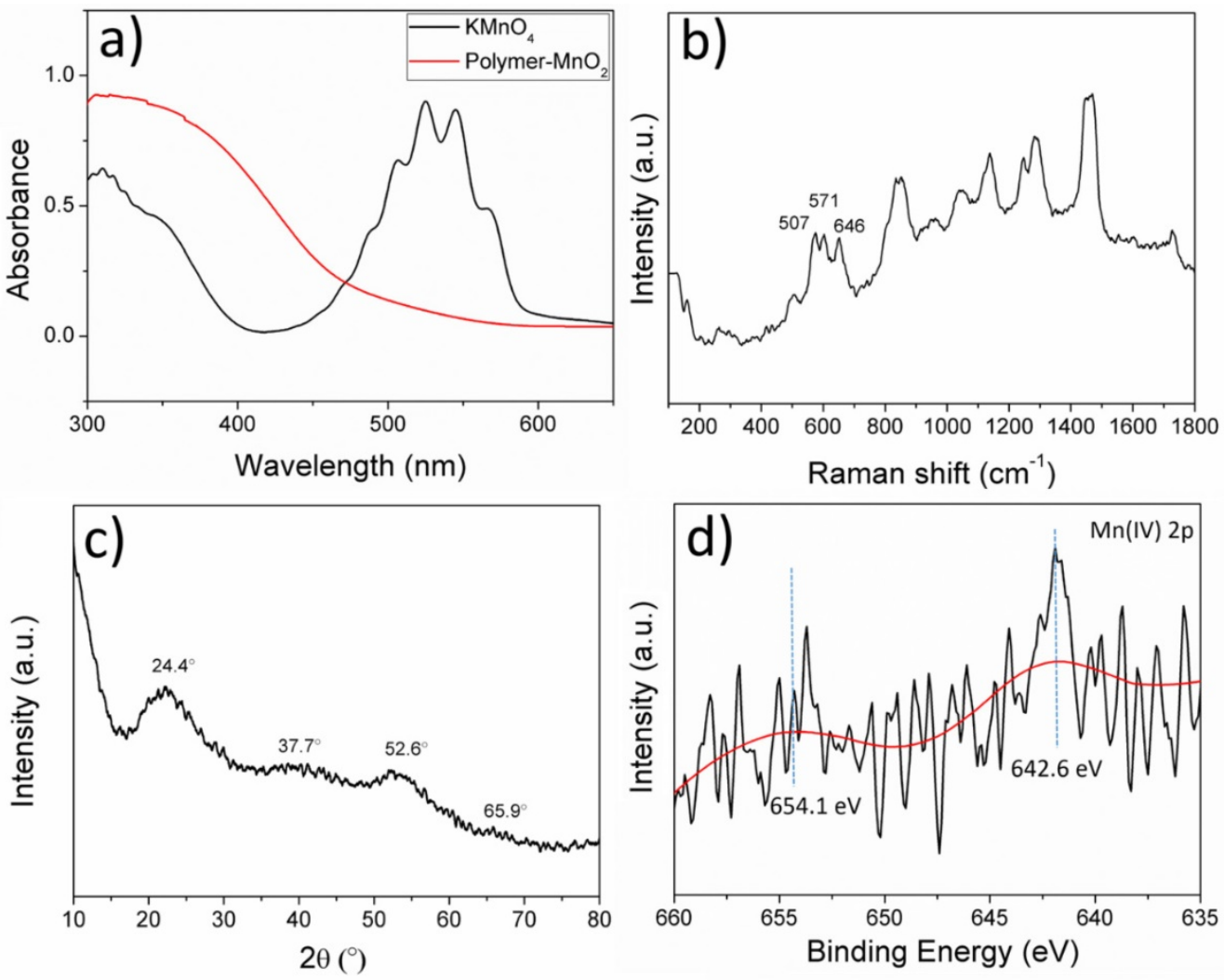

Figure 2. (a) UV-vis absorption spectra of $\mathrm{KMnO}_{4}$ and PM NPs in deionized water solutions at room temperature; (b) Raman spectrum of PMB NPs; (c) XRD spectrum of PMB NPs and (d) XPS spectrum of PMB NPs.

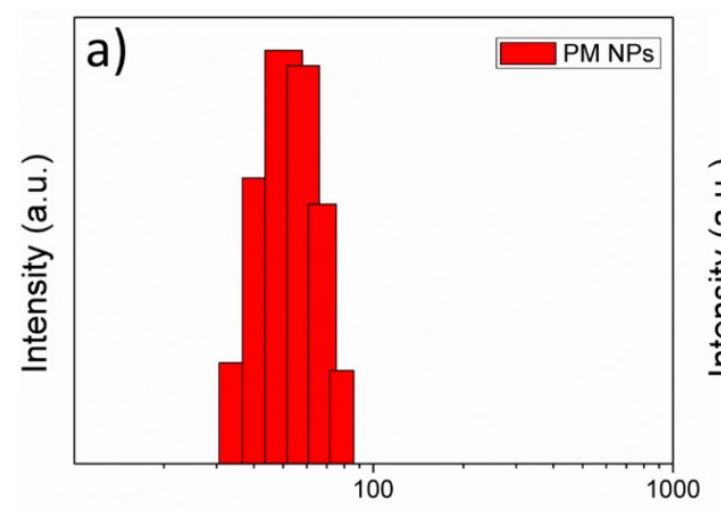

Size $(\mathrm{nm})$

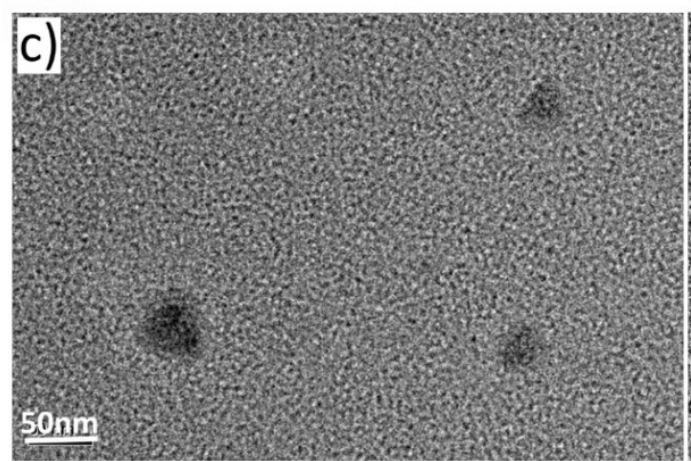

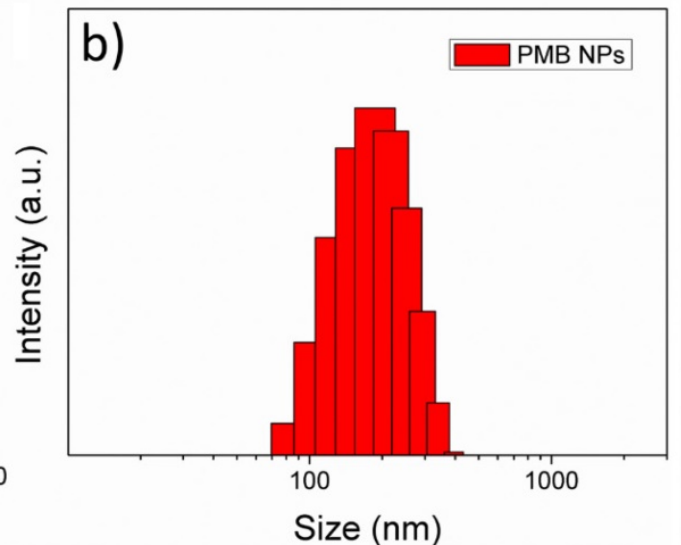

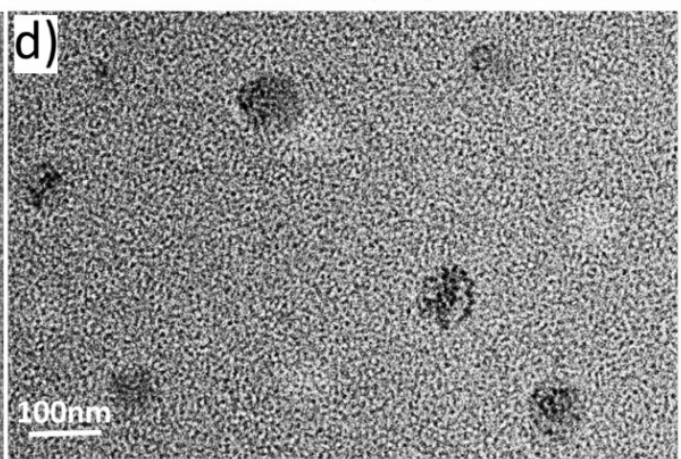

Figure 3. Size distribution of (a) PM NPs and (b) PMB NPs; TEM image of (c) PM NPs and (d) PMB NPs. 


\section{Oxygen Generation and Singlet Oxygen Detection}

Upon reaction with $\mathrm{H}_{2} \mathrm{O}_{2}$ at an endogenous level,[31] we first investigated the functionality of PM NPs to generate $\mathrm{O}_{2}$. Reaction between $\mathrm{MnO}_{2}$ and $\mathrm{H}_{2} \mathrm{O}_{2}$, which is summarized in Figure $4 \mathrm{a}$, is a complex reaction to produce $\mathrm{O}_{2}$ by the consumption of $\mathrm{H}^{+}$ions and decomposition of $\mathrm{H}_{2} \mathrm{O}_{2}$. In a nitrogen-filled and hypoxia-maintaining chamber coupled with a dissolved oxygen analyzer, significant amounts of $\mathrm{O}_{2}$ were produced by the reaction of $\mathrm{MnO}_{2}(45 \mu \mathrm{M})$ with $\mathrm{H}_{2} \mathrm{O}_{2}(100 \mu \mathrm{M})$, accompanied by an increase of $\mathrm{pH}$ from 6.0 (phosphate/saline buffer, simulating the tumor cells $\mathrm{pH}$ ) to 8.4 (Figure $4 \mathrm{~b}$ ). These results elucidated that $\mathrm{H}_{2} \mathrm{O}_{2}$ and $\mathrm{H}^{+}$ions could diffuse freely into the reactive sites of the $\mathrm{MnO}_{2}$ cores in PM NPs, followed by $\mathrm{O}_{2}$ production and $\mathrm{pH}$ increase under hypoxia conditions.

Considering the fact that $\mathrm{H}_{2} \mathrm{O}_{2}$ is continuously generated in tumor cells, as shown in Figure 4c, we attempted to simulate the in vivo conditions by continuously adding $\mathrm{H}_{2} \mathrm{O}_{2}(250 \mu \mathrm{M})$ every $30 \mathrm{~min}$ with a preliminary concentration of $\mathrm{MnO}_{2}(300 \mu \mathrm{M})$. We observed a single dose of the PMB NPs could continuously generate $\mathrm{O}_{2}$ for five cycles of $30 \mathrm{~min}$. Furthermore, if we conduct the reaction in a smaller vessel, abundant oxygen bubbles were observed, vividly demonstrating the strong capability of $\mathrm{MnO}_{2}$ to induce $\mathrm{H}_{2} \mathrm{O}_{2}$ decomposition and $\mathrm{O}_{2}$ generation (Figure S4).

a)

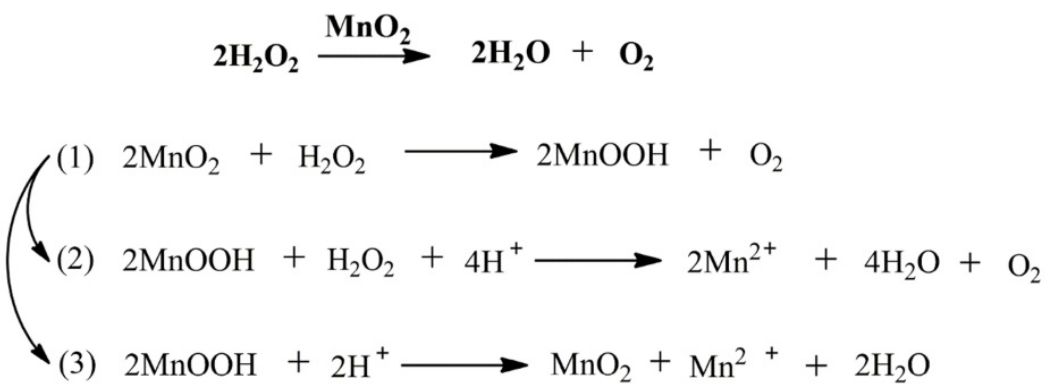

(4) $\mathrm{MnO}_{2}+\mathrm{H}_{2} \mathrm{O}_{2}+2 \mathrm{H}^{+}$ $\mathrm{Mn}^{2+}+2 \mathrm{H}_{2} \mathrm{O}+\mathrm{O}_{2}$
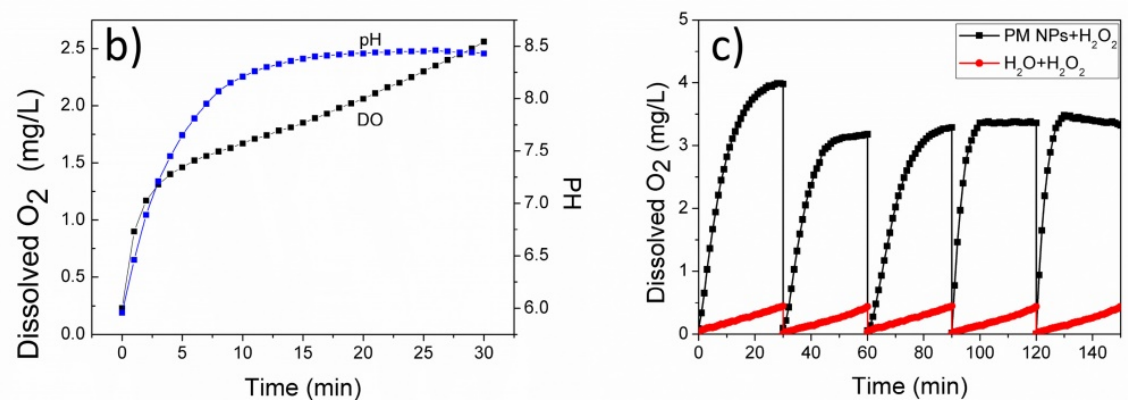

Figure 4. Reactivity of $\mathrm{PM} N \mathrm{NP}$ toward $\mathrm{H}_{2} \mathrm{O}_{2}$ : (a) Reaction $\mathrm{MnO}_{2}$ with $\mathrm{H}_{2} \mathrm{O}_{2}$ to produce $\mathrm{O}_{2}$ at the presence of $\mathrm{H}^{+}$; (b) $\mathrm{O}_{2}$ generation and $\mathrm{pH}$ increase by reaction of $\mathrm{PM} \mathrm{NPs}$ with $\mathrm{H}_{2} \mathrm{O}_{2}$; (c) $\mathrm{O}_{2}$ generation by continuous addition of $\mathrm{H}_{2} \mathrm{O}_{2}$ to PMB NPs solution.
In addition, we measured the ${ }^{1} \mathrm{O}_{2}$ generation rate of PMB NPs in aqueous solution by the UV absorbance decrease of DPBF (an indicator of ${ }^{1} \mathrm{O}_{2}$ ), as shown in Figure 5. Under 635nm irradiation, the absorbance of DBPF at $425 \mathrm{~nm}$ decreased sharply every $1 \mathrm{~min}$ irradiation, indicating the high efficiency of the generation of singlet oxygen. In addition, there are no obvious subtraction of BODIPY absorbance, implying its outstanding photostability during PDT treatment.

\section{Cancer Cells Uptake and PDT Cytotoxicity of PMB NPs}

It is reported that the cancer cellular concentration of $\mathrm{H}_{2} \mathrm{O}_{2}$ significantly elevated because of the aberrant metabolism.[32] We hypothesized that the PMB NPs could react with endogenous $\mathrm{H}_{2} \mathrm{O}_{2}$, if they were taken up by cancer cells under hypoxic stress, thus producing $\mathrm{O}_{2}$ in situ and then acting on PDT. To prove this, the cellular uptake experiments of PMB NPs by human HepG2 and murine $4 \mathrm{~T} 1$ cells were both carried out. Cancer cells were firstly incubated with nanoparticles for different periods of time, and then observed through fluorescence imaging. As shown in Figure 6 , the fluorescence intensity of BODIPY increased obviously over time in the cytoplasm and perinuclear region, which illustrated the endocytosis of the nanoparticles into cancer cells with favorable cytocompatibility (Figure S5).

The cancer cell killing efficacy of PMB NPs in a series of different conditions was then tested. MTT assays against HepG2 and 4T1 cells were conducted at normal or hypoxia atmosphere. Moreover, the effect of $\mathrm{MnO}_{2}$ against $\mathrm{H}_{2} \mathrm{O}_{2}$ on PDT efficiency was measured by incubating cells with or without exogenous $100 \mu \mathrm{M}$ $\mathrm{H}_{2} \mathrm{O}_{2}$ added for $4 \mathrm{~h}$ at hypoxia atmosphere.

Generally, a $635 \mathrm{~nm}$ lamp was used for the irradiation experiments. Cells were irradiated for $10 \mathrm{~min}$ with power density of $25 \mathrm{~mW} / \mathrm{cm}^{2}$, which was extremely low as far as reported. As shown in Figure 7, PMB NPs did not show too much cytotoxicity to cells under dark. However, in normal $\left(5 \% \mathrm{CO}_{2}\right)$ atmosphere, the suppression rates keep gradually increased as the concentration of BODIPY increased when light irradiation was added. At a 
concentration of $12.9 \mu \mathrm{M}$, the mortality of the cells increased appreciably with irradiation, 36\% HepG2 cells and 43\% 4T1 cells dies higher than that incubated under dark.
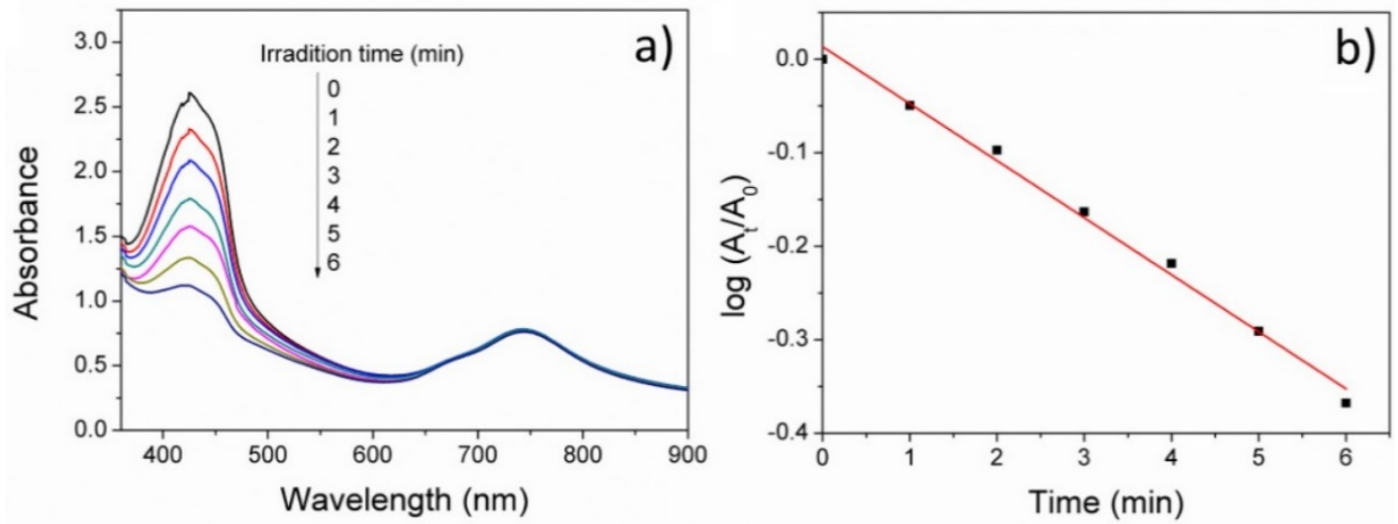

Figure 5. (a) UV-vis absorption spectra of DPBF upon irradiation with PMB NPs in $2 \%$ DMSO-water solution under $635 \mathrm{~nm}$ irradiation, and (b) plots of absorbance decrease of DPBF at $425 \mathrm{~nm}$ at different irradiation times at room temperature.

a)
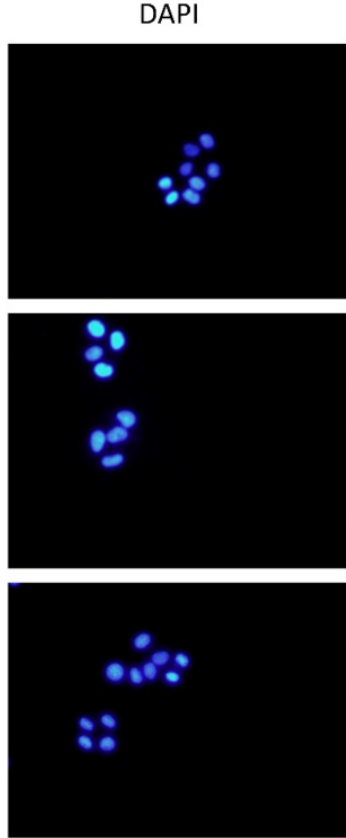

b)
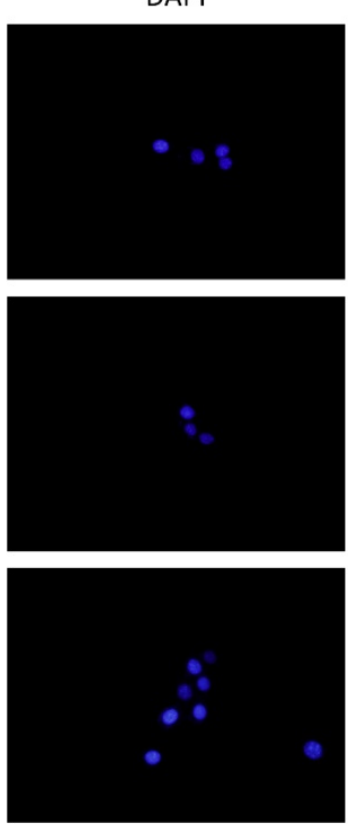

BODIPY
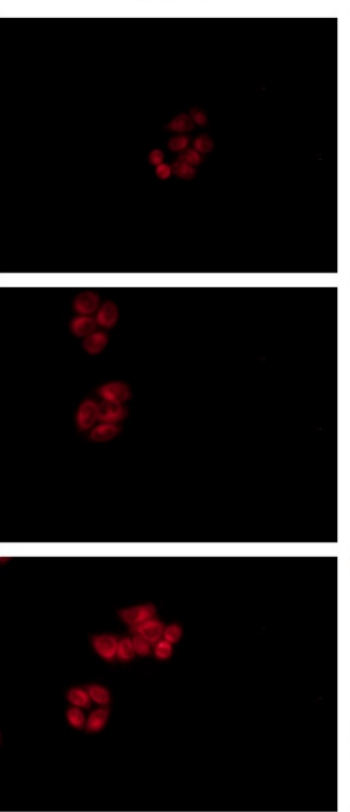

BODIPY
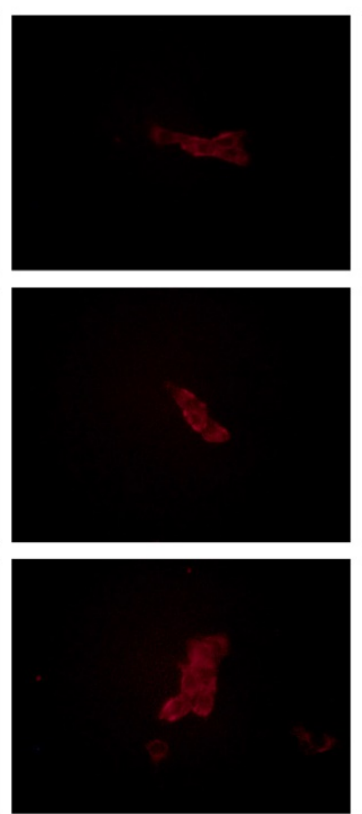

Merge

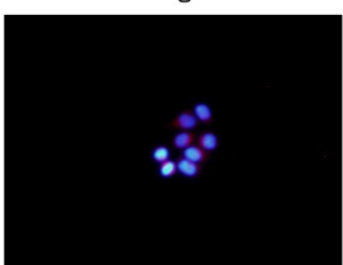

$8 \mathrm{~h}$

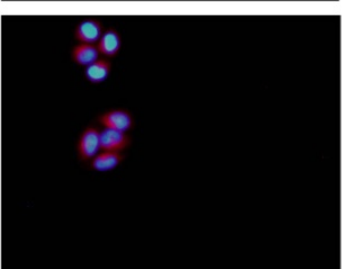

$12 \mathrm{~h}$

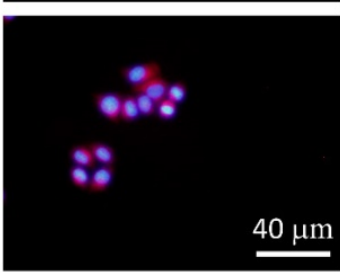

Merge

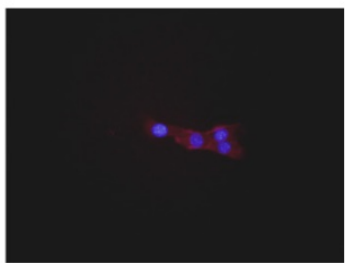

$8 \mathrm{~h}$

$12 \mathrm{~h}$

$24 \mathrm{~h}$ 

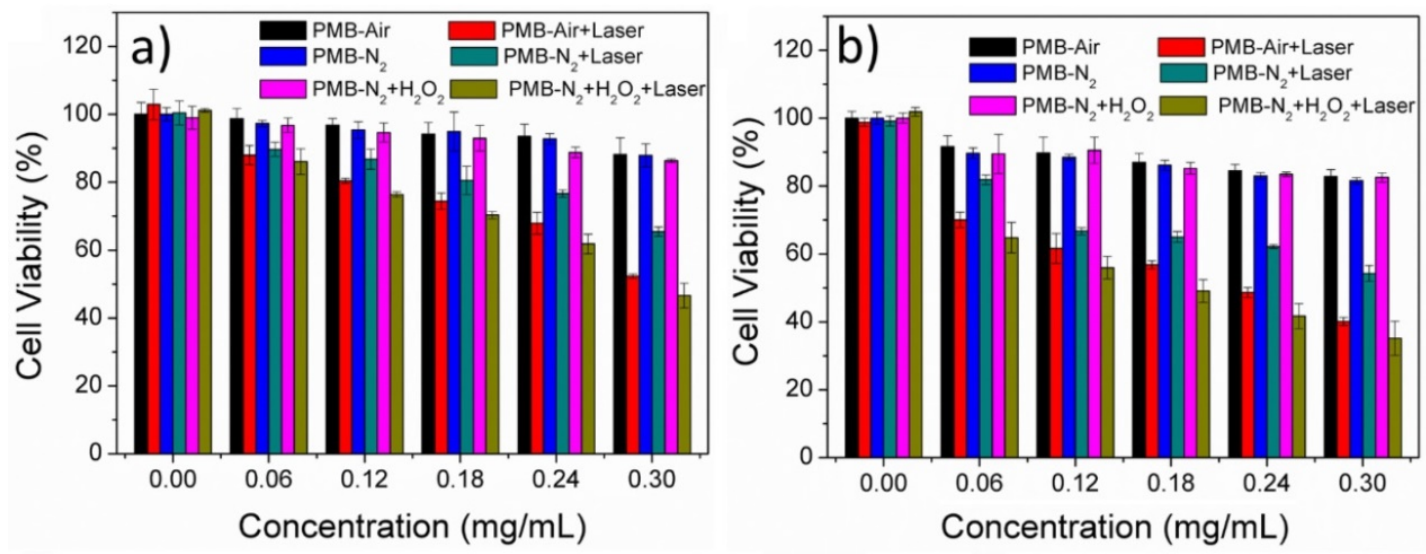

Figure 7. Cytotoxicity of PMB NPs to (a) HepG2 and (b) $4 \mathrm{~T} 1$ cells with or without irradiation under different conditions.

Figure 8. FDA/PI dyed images of cancer cells treated PMB or PB NPs with or without illumination (635nm, 25mW/cm2, $10 \mathrm{~min}$ ) and $\mathrm{H}_{2} \mathrm{O}_{2}$ : (a) $\mathrm{HepG} 2$ and (b) 4T1 cells under normal atmosphere; (c) HepG2 and (d) 4T1 cells under hypoxia atmosphere.

Then, in the nitrogen atmosphere, the added NPs exhibited no distinct dark cytotoxicity to cancer cells with additional $\mathrm{H}_{2} \mathrm{O}_{2}$ added. However, under light irradiation, the PDT efficiency enhanced obviously (25\% suppression rate), especially after the addition of $\mathrm{H}_{2} \mathrm{O}_{2}$ (upto extra $20 \%$ suppression rate increased), nearly similar to the suppression rates with the same BODIPY concentrations incubated in normal atmosphere. At the same time, nanoparticles without $\mathrm{MnO}_{2}$ (polymer-BODIPY, PB NPs) was also prepared referencing our previous work, [33] and the PDT efficiency of PB NPs was tested in a similar way (Figure S6). Interestingly, we found that the adding exogenous $\mathrm{H}_{2} \mathrm{O}_{2}$ could only enhance the PDT efficacy of PMB NPs with $\mathrm{MnO}_{2}$ but not for PB NPs without $\mathrm{MnO}_{2}$.

In another way to study the PDT effect on cancer cells, imaging of dead (red) and live (green) cells was carried out with propidium iodide (PI) and fluorescein diacetate (FDA) staining. Coincidentally, the FDA/PI dyeing tests conformed to the MTT results perfectly. With no obvious cytotoxicity in dark, the growth of both HepG2 and 4T1 cells was effectively expressed under light irradiation, presenting lower cell density and more dead cells compared to the control groups (Figure 8). More
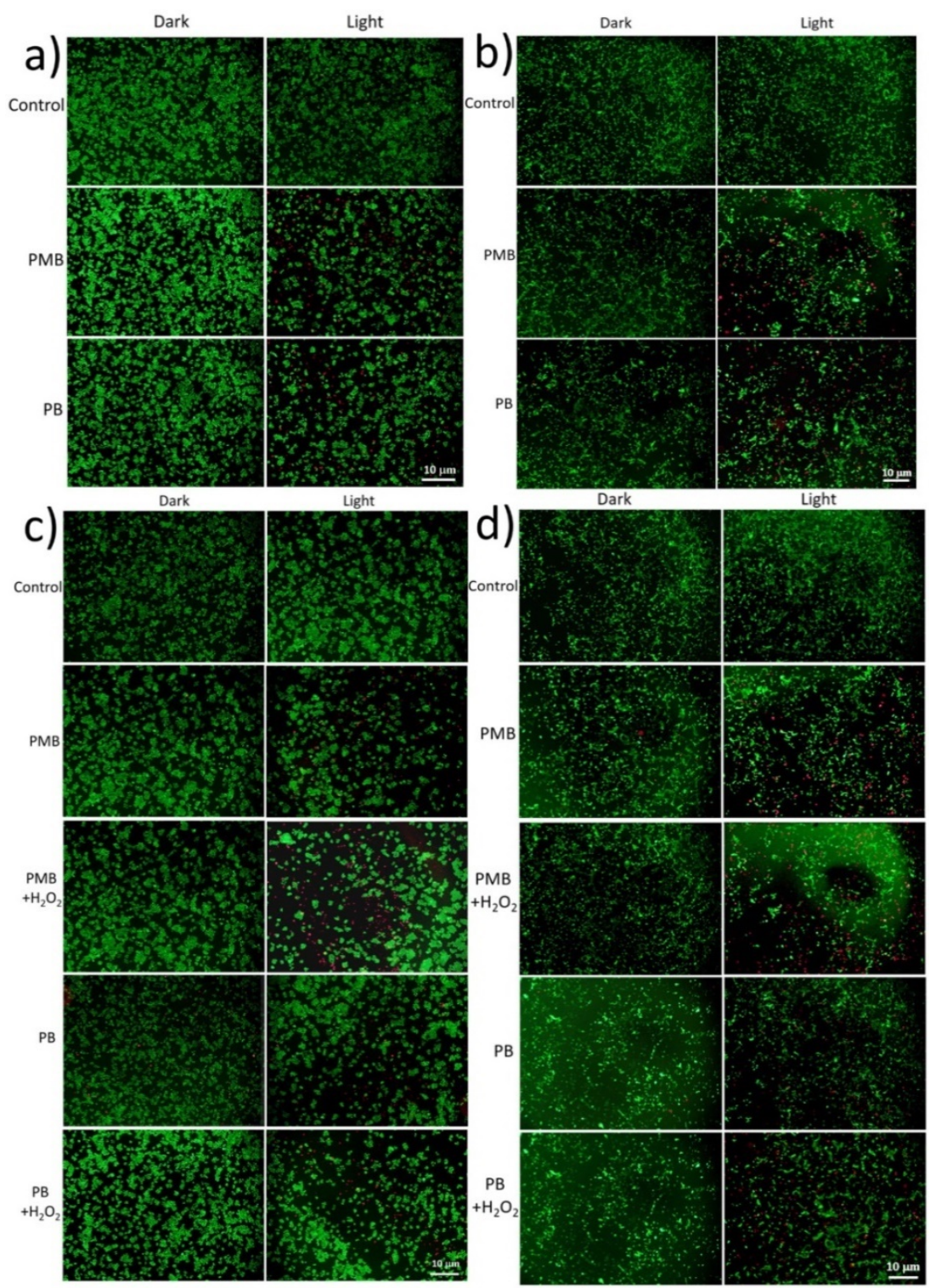

importantly, under hypoxia condition, PMB NPs exhibited satisfactory cytotoxicity with light irradiation and $\mathrm{H}_{2} \mathrm{O}_{2}$ added. More importantly, we conducted DAPI staining assay against HepG2 cells to observe the cell nucleus transformation in the whole PDT process. With no obvious change in dark, the nuclei of HepG2 cells shrunk $2 \mathrm{~h}$ after light irradiation compared to the control groups, and 
increasing number of nuclei became out of shape over time (Figure 9). These results clearly revealed a light driving and $\mathrm{H}_{2} \mathrm{O}_{2}$ elevating photodynamic therapy property of the as-prepared PMB NPs.

Dark

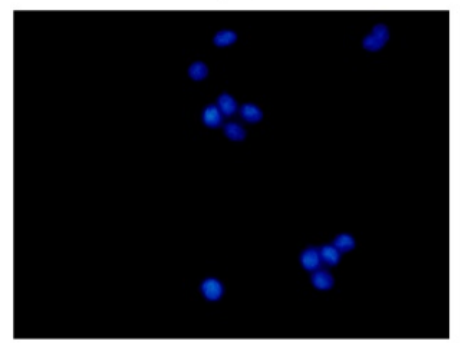

$2 \mathrm{~h}$

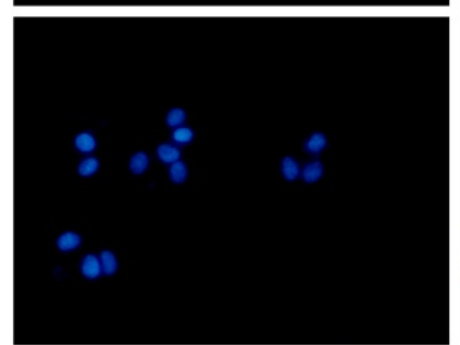

$4 \mathrm{~h}$

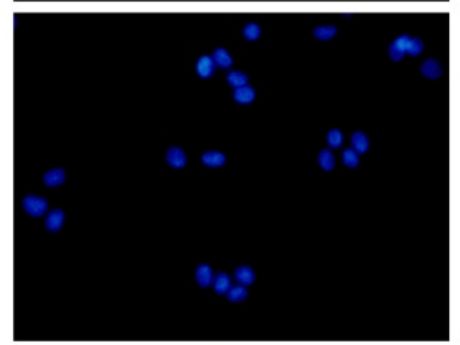

$8 \mathrm{~h}$
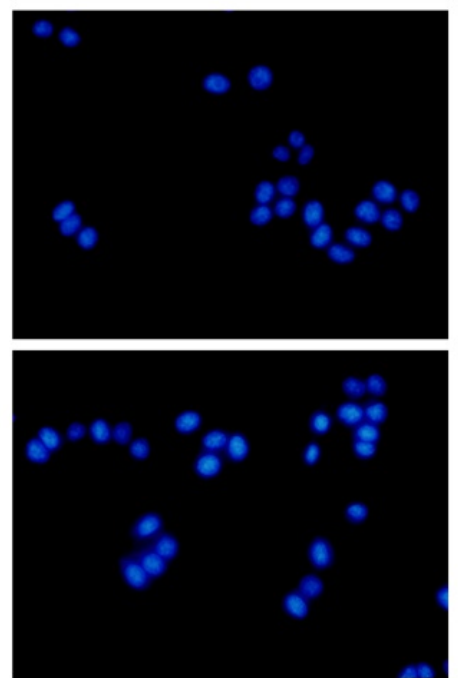

$12 \mathrm{~h}$

$24 h$

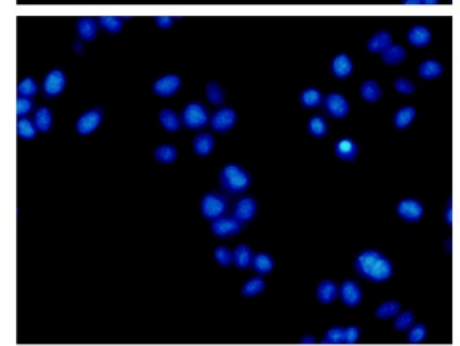

Figure 9. DAPI dyed cell apoptosis images of HepG2 cells treated PMB NPs with or without illumination $\left(635 \mathrm{~nm}, 25 \mathrm{~mW} / \mathrm{cm}_{2}, 10 \mathrm{~min}\right)$ under hypoxia atmosphere.

\section{Light}
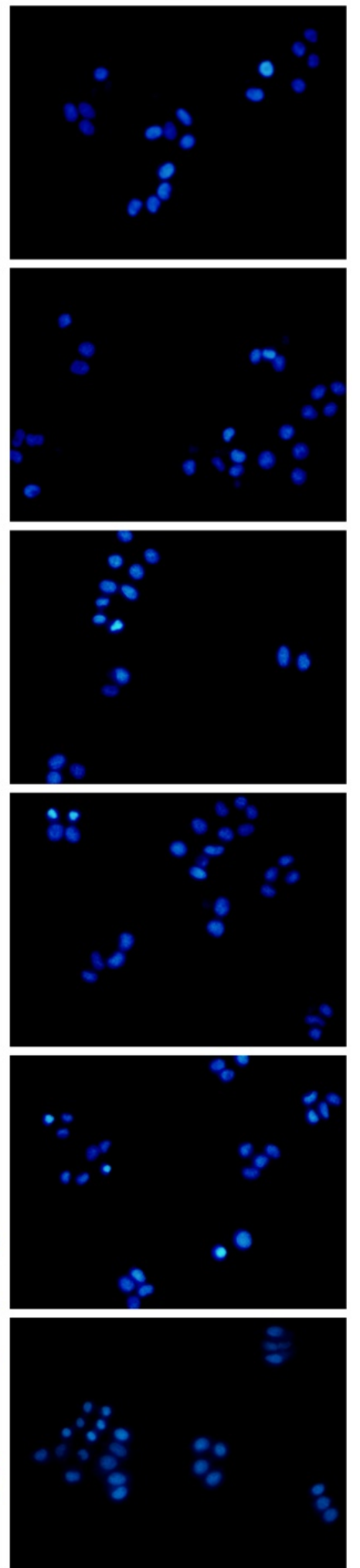

\section{Conclusions}

In conclusion, multifunctional $\mathrm{H}_{2} \mathrm{O}_{2}$ reactive polymer- $\mathrm{MnO}_{2}$-BODIPY nanoparticles (PMB NPs) were successfully prepared through a simple one-step amino-based reduction reaction followed by emulsion encapsulating method for effective image-guided photodynamic therapy in hypoxia

\section{References}

1. Calixto GMF, Bernegossi J, de Freitas LM, Fontana CR, Chorilli M. Nanotechnology-Based Drug Delivery Systems for Photodynamic Therapy of Cancer: A Review. Molecules. 2016; 21:342-8

2. Chan MH, Pan YT, Lee IJ, Chen CW, Chan YC, Hsiao $M$, et al. Minimizing the Heat Effect of Photodynamic Therapy Based on Inorganic Nanocomposites Mediated by $808 \mathrm{~nm}$ Near-Infrared Light. Small. 2017; 13: DOI:10.1002/smll.201700038

3. Gursoy H, Ozcakir-Tomruk C, Tanalp J, Yilmaz S. Photodynamic therapy in dentistry: a literature review. Clin Oral Invest. 2013; 17: 1113-25.

4. Luo T, Zhang QR, Lu QB. Combination of Near Infrared Light-Activated Photodynamic Therapy Mediated by Indocyanine Green with Etoposide to Treat Non-Small-Cell Lung Cancer. Cancers. 2017; 9:63. 
5. Qiu KQ, Wang JQ, Song CL, Wang LL, Zhu HY, Huang HY, et al. Crossfire for Two-Photon Photodynamic Therapy with Fluorinated Ruthenium (II) Photosensitizers. Acs Appl Mater Inter. 2017; 9: 18482-92.

6. Kamkaew A, Lim SH, Lee HB, Kiew LV, Chung LY, Burgess K. BODIPY dyes in photodynamic therapy. Chem Soc Rev. 2013; 42: 77-88.

7. Awuah SG, Polreis J, Biradar V, You Y. Singlet Oxygen Generation by Novel NIR BODIPY Dyes. Org Lett. 2011; 13: 3884-7.

8. Choi SY, Baek SH, Chang SJ, Song Y, Rafique R, Lee KT, et al. Synthesis of upconversion nanoparticles conjugated with graphene oxide quantum dots and their use against cancer cell imaging and photodynamic therapy. Biosens Bioelectron. 2017; 93: 267-73.

9. Gao M, Fan F, Li DD, Yu Y, Mao KR, Sun TM, et al. Tumor acidity-activatable TAT targeted nanomedicine for enlarged fluorescence/magnetic resonance imaging-guided photodynamic therapy. Biomaterials. 2017; 133: 165-75.

10. Guo L, Ge JC, Liu Q, Jia QY, Zhang HY, Liu WM, et al. Versatile Polymer Nanoparticles as Two-Photon-Triggered Photosensitizers for Simultaneous Cellular, Deep-Tissue Imaging, and Photodynamic Therapy. Adv Healthc Mater. 2017; 6: 1601431

11. Kamimura M, Omoto A, Chiu HC, Soga K. Enhanced Red Upconversion Emission of NaYF4:Yb3+, Er3+, Mn2+ Nanoparticles for Near-infrared-induced Photodynamic Therapy and Fluorescence Imaging. Chem Lett. 2017; 46: 1085-7.

12. Zhang PC, Zhang ZH, Jiang XZ, Rui LL, Gao Y, Zhang WA. Unimolecular micelles from POSS-based star-shaped block copolymers for photodynamic therapy. Polymer. 2017; 118: 268-79.

13. An FF, Zhang XH. Pure photosensitizer nanocrystals stabilized with amphiphilic multidentate polymer ligands on the surface for ultra-high payload and enhanced photodynamic therapy. J Control Release. 2013; 172: E29.

14. Castriciano MA, Zagami R, Casaletto MP, Martel B, Trapani M, Romeo A, et al. Poly(carboxylic acid)-Cyclodextrin/Anionic Porphyrin Finished Fabrics as Photosensitizer Releasers for Antimicrobial Photodynamic Therapy. Biomacromolecules. 2017; 18: 1134-44.

15. Li J, Zhang WD, Hu ZJ, Jiang XJ, Ngai T, Lo PC, et al. Novel phthalocyanine and PEG-methacrylates based temperature-responsive polymers for targeted photodynamic therapy. Polym Chem-Uk. 2013; 4: 782-8.

16. Ariffin $\mathrm{AB}$, Forde $\mathrm{PF}$, Jahangeer $\mathrm{S}$, Soden DM, Hinchion J. Releasing Pressure in Tumors: What Do We Know So Far and Where Do We Go from Here? A Review. Cancer Res. 2014; 74: 2655-62.

17. Broekgaarden M, Weijer R, Krekorian M, van den IJssel B, Kos M, Alles LK, et al. Inhibition of hypoxia-inducible factor 1 with acriflavine sensitizes hypoxic tumor cells to photodynamic therapy with zinc phthalocyanine-encapsulating cationic liposomes. Nano Res. 2016; 9 ; 1639-62.

18. Luo ZY, Zheng MB, Zhao PF, Chen $Z$, Siu FM, Gong $P$, et al Self-Monitoring Artificial Red Cells with Sufficient Oxygen Supply for Enhanced Photodynamic Therapy. Sci Rep. 2016; 6: 23393.

19. Jung HS, Han J, Shi H, Koo S, Singh H, Kim HJ, et al. Overcoming the Limits of Hypoxia in Photodynamic Therapy: A Carbonic Anhydrase IX-Targeted Approach. J Am Chem Soc. 2017; 139: 7595-602.

20. Liu CP, Wu TH, Liu CY, Chen KC, Chen YX, Chen GS, et al. Self-Supplying O-2 through the Catalase-Like Activity of Gold Nanoclusters for Photodynamic Therapy against Hypoxic Cancer Cells. Small. 2017; 13: 1700278 .

21. Cheng $\mathrm{YH}$, Cheng $\mathrm{H}$, Jiang $\mathrm{CX}$, Qiu XF, Wang $\mathrm{KK}$, Huan $\mathrm{W}$, et al Perfluorocarbon nanoparticles enhance reactive oxygen levels and tumour growth inhibition in photodynamic therapy. Nat Commun. 2015; 6:8785.

22. Chen $\mathrm{Q}$ Feng LZ, Liu JJ, Zhu WW, Dong ZL, Wu YF, et al. Intelligent Albumin-MnO2 Nanoparticles as $\mathrm{pH}-/ \mathrm{H} 2 \mathrm{O} 2-\mathrm{Responsive}$ Dissociable Nanocarriers to Modulate Tumor Hypoxia for Effective Combination Therapy. Adv Mater. 2016; 28: 7129-32.

23. Jing TT, Fu LY, Liu L, Yan LF. A reduction-responsive polypeptide nanogel encapsulating NIR photosensitizer for imaging guided photodynamic therapy. Polym Chem. 2016; 7: 951-7.

24. Fu LY, Sun CY, Yan LF. Galactose Targeted pH-Responsive Copolymer Conjugated with Near Infrared Fluorescence Probe for Imaging of Intelligent Drug Delivery. Acs Appl Mater Inter. 2015; 7: 2104-15.

25. Prasad P, Gordijo CR, Abbasi AZ, Maeda A, Ip A, Rauth AM, et al Multifunctional Albumin-MnO2 Nanoparticles Modulate Solid Tumor Microenvironment by Attenuating Hypoxia, Acidosis, Vascular Endothelial Growth Factor and Enhance Radiation Response. Acs Nano. 2014; 8: 3202-12.

26. Gordijo CR, Abbasi AZ, Amini MA, Lip HY, Maeda A, Cai P, et al. Design of Hybrid MnO2-Polymer-Lipid Nanoparticles with Tunable Oxygen Generation Rates and Tumor Accumulation for Cancer Treatment. Adv Funct Mater. 2015; 25: 1858-72

27. Julien C, Massot M, Rangan S, Lemal M, Guyomard D. Study of structural defects in gamma-MnO2 by Raman spectroscopy. J Raman Spectrosc. 2002; 33: $223-8$.

28. Wu SS, Chen WF, Yan LF. Fabrication of a 3D MnO2/graphene hydrogel for high-performance asymmetric supercapacitors. Journal of Materials Chemistry A. 2014; 2: 2765-72

29. Filatov MA, Karuthedath S, Polestshuk PM, Savoie H, Flanagan KJ, Sy C, et al. Generation of Triplet Excited States via Photoinduced Electron Transfer in meso-anthra-BODIPY: Fluorogenic Response toward Singlet Oxygen in Solution and in Vitro. J Am Chem Soc. 2017; 139: 6282-5.

30. Liu L, Fu LY, Jing TT, Ruan Z, Yang LF. pH-Triggered Polypeptides Nanoparticles for Efficient BODIPY Imaging-Guided Near Infrared Photodynamic Therapy. Acs Appl Mater Inter. 2016; 8: 8980-90.
31. Peng J, Hou XF, Zeng F, Wu SZ. Fluorescent nanoprobe for in-vivo ratiometric imaging of endogenous hydrogen peroxide resulted from drug-induced organ damages. Biosens Bioelectron. 2017; 94: 278-85.

32. Lopez-Lazaro M. Dual role of hydrogen peroxide in cancer: Possible relevance to cancer chemoprevention and therapy. Cancer Lett. 2007; 252: $1-8$.

33. Liu L, Ruan Z, Li TW, Yuan P, Yan LF. Near infrared imaging-guided photodynamic therapy under an extremely low energy of light by galactose targeted amphiphilic polypeptide micelle encapsulating BODIPY-Br-2. Biomater Sci. 2016; 4: 1638-45. 